\title{
BASES FOR PUMP PIT REQUIREMENTS CALCULATIONS (U)
}

WSRC-RP- $-92-302$

by R. A. Jacobs

DE93 003377

Westinghouse Savannah River Company

Savannah River Site

Aiken, South Carolina 29808

Other Authors:

\section{DISCLAIMER}

This report was prepared as an account of work sponsored by an agency of the United States Government. Neither the United States Government nor any agency thereof, nor any of their Government. Neither the United express or implied, or assumes any legal liability or responsibility for the accuracy, completeness, or usefulness of any information, apparatus, product, or process disclosed, or represents that its use would not infringe privately owned rights. Reference herein to any specific commercial product, process, or service by trade name, trademark, ence herein to any specific comme not necessarily constitute or imply its endorsement, recommendation, or favoring by the United States Government or any agency thereof. The views and opinions of authors expressed herein do not necessarily state or reflect those of the United States Government or any agency thereof.

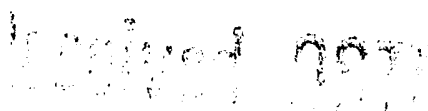

$$
\text { Noy } 271952
$$

This paper was prepared in connection with work done under Contract No. DE-AC09-89SR18035 with the U. S. Department of Energy. By acceptance of this paper, the publisher and/or recipient acknowledges the U. S. Government's right to retain a nonexclusive, royalty-free license in and to any copyright covering this paper, along with the right to reproduce and to authorize others to reproduce all or part of the copyrighted paper.

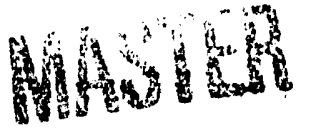




\section{DISCLAIMER}

This report was prepared as an account of work sponsored by an agency of the United States Government. Neither the United States Government nor any agency thereof, nor any of their employees, makes any warranty, express or implied, or assumes any legal liability or responsibility for the accuracy, completeness, or usefulness of any information, apparatus, product, or process disclosed, or represents that its use would not infringe privately owned rights. Reference herein to any specific commercial product, process, or service by trade name, trademark, manufacturer, or otherwise does not necessarily constitute or imply its endorsement, recommendation, or favoring by the United States Government or any agency thereof. The views and opinions of authors expressed herein do not necessarily state or reflect those of the United States Government or any agency thereof.

This report has been reproduced directly from the best available copy.

Available to DOE and DOE contractors from the Office of Scientific and Technical Information, P.O. Box 62, Oak Ridge, TN 37831; prices available from (615) 576-8401, FTS 626-8401.

Available to the public from the National Technical Information Service, U.S. Department of Commerce, 5285 Port Royal Rd., Springfield, VA 22161. 


\title{
INTER-OFFICE MEMORANDUM
}

\author{
WSRC-RP-92-0302 \\ Keywords: DWPF, pump pits, \\ benzene, hydrogen, \\ Process Requirements \\ Retention period: Permanent \\ CC: J. M. Gillam, 704-27S \\ M. R. Norton, 704-27S \\ N. E. Bibler, 773-A \\ D. D. Walker, 773-A \\ L. F. Landon, 704-T \\ SRI Records (4)* \\ February 13, 1992
}

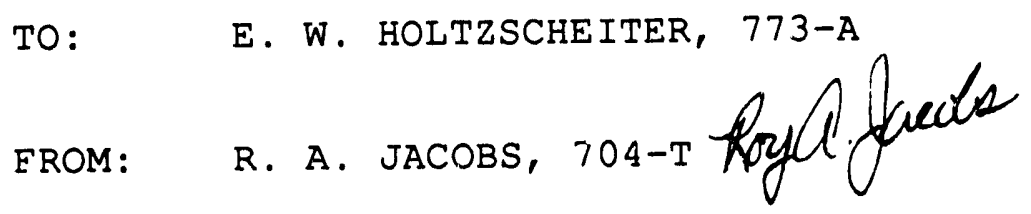

BASTS FOR PUMP PIT PROCESS REOUIRFMTNTS CALCUTATIONS (U)

\section{Summary}

A task team is preparing the Process Requirements for the interarea transfer pump pits. The team is developing requirements to prevent flammable mixtures from forming and requires values to use on the generation of various components such as benzene, hydrogen, and 20 . The purpose of this memorandum is to document values to be used and to provide sample calculations using these values. There are no recommendations contained in this document.

Note: All vapor concentrations are in volume percent.

\section{Bydregen Generation from the sludoe Pump Pit Tank}

Hydrogen is generated from sludge by radiolysis. [1] The rate of $\mathrm{H} 2$ formation is estimated using a $G$ value of 0.45 molecules/100eV (recommended by the NRC[2]) and a specific activity for the sludge of 0.44 watts/gal (five year out-of-reactor sludge). [3,4]

जी 1 Tarter, 704-1T
Authorized Derivative Classifier 
Assuming 6500 gallons sludge and allowing for $50 \%$ higher activity than in the curie balance, the hydrogen formation rate in the solution is

$$
\begin{aligned}
& 6500 \mathrm{gal} \times \frac{1.5 \times 0.44 \text { watts }}{\mathrm{gal}} \times \frac{2.25 \times 10^{22} \mathrm{eV}}{\text { watt } \mathrm{hr}} \times \frac{0.45 \mathrm{molecules}}{100 \mathrm{eV}} \\
& \times \frac{1 \mathrm{gmol}}{6.023 \times 10^{23} \mathrm{molecules}} \times \frac{1 \mathrm{lbmol}}{453.6 \mathrm{gmol}} \times \frac{359 \mathrm{scf}}{1 \mathrm{bmol}}=0.57 \mathrm{scfh}
\end{aligned}
$$

where standard conditions are $0^{\circ} \mathrm{C}$ and 14.7 psia.

A conservative estimate of the evolution is that it is equal to the rate of formation in the liquid. This does not take into account that nitrate ions will react with $\mathrm{H} 2$ precursors.[1] Also not included are effects of $\mathrm{H} 2$ solubility, diffusion, and mass transfer. Actual generation rates from the liquid surface will be significantly lower, perhaps by a factor of two or three.

\section{Bydrogen Generation from the Precipitate shuray}

Fydrogen is also generated from the precipitate slurry. The $G$ value is 0.46 molecules $/ 100 \mathrm{eV}$ [5] and the specific activity from the curie balance is 0.17 watts/gal $[3,4]$ for 15 year out-ofreactor saltcake ( $36 \mathrm{Ci} / \mathrm{gal} \mathrm{Cs}-137,71 \mathrm{Ci} / \mathrm{gal}$ total). Allowing for $50 \%$ higher activity, the calculation for 6500 gallons precipitate slurry is

$$
\begin{aligned}
& 6500 \mathrm{gal} \times \frac{1.5 \times 0.17 \text { watts }}{\text { gal }} \times \frac{2.25 \times 10^{22} \mathrm{eV}}{\text { watt } \mathrm{hr}} \times \frac{0.46 \text { molecules }}{100 \mathrm{eV}} \\
& \times \frac{1 \mathrm{gmol}}{6.023 \times 10^{23} \mathrm{molecules}} \times \frac{1 \mathrm{lbmol}}{453.6 \mathrm{gmol}} \times \frac{359 \mathrm{scf}}{1 \mathrm{bmol}}=0.23 \mathrm{scfh}
\end{aligned}
$$

\section{Minimum o2 for combustion (MOC) for $82 /$ Benzene Mixtures}

The Precipitate Pump Tank (PPT) will be purged with N2 and the 02 concentration measured to ensure that insufficient 02 is present for combustion; that is, it will be maintained below the MOC of $11.4 \% 02$ for combustion of benzene in air with $\mathrm{N} 2$ as diluent. [6] Under normal conditions, N2 purge flows through the PPT should be at least $20 \mathrm{scfm}$. From the above estimation of $0.23 \mathrm{scfh} H 2$ generation, the expected $\mathrm{H} 2$ at normal conditions would be < $0.02 \%$. At this concentration, the $\mathrm{H} 2$ will have essentially no affect on the MOC for benzerie.

However, loss of the Process Vessel Vent System (PVVS) will result in much reduced flows. If this occurs, DWP will provide a minimum air flow to prevent buildup of $\mathrm{H} 2$. 'Since the MOC for $\mathrm{H} 2$ in air (with N2 as diluent) is only 5\%[6], the presence of $\mathrm{H} 2$ will serve to reduce the MOC of the of the mixed fuel. Previous

$$
-2-
$$


flammability studies recommended using an MOC of $9.0 \% 02$ for fuel mixtures containing up to a $90 / 10$ ratio of benzene to H2. [7] The composite LEL of a mixture can be estimated by

$$
L E L_{\text {comp }}=\frac{100}{\frac{C_{1}}{L_{1}}+\frac{C_{2}}{L_{2}}}
$$

where $\mathrm{C}_{\mathrm{n}}=$ concentration of fuel $\mathrm{n}$ as $\frac{\circ}{\mathrm{a}}$ of tolal oxidants $L_{n}=L E L$ for fuel $n$.

For $C_{1}=90 \%, L_{1}=1.3 \%[8], C_{2}=10 \%$, and $L_{2}=4.0 \%$,

$$
L E L_{\text {comp }}=\frac{100}{\frac{90}{1.3}+\frac{10}{4.0}}=1.394 \%
$$

Therefore an MOC of $9.0 \%$ O2 can be used for a H2 concentration up to $0.14 \%$. At $0.23 \mathrm{scfh}$ of $\mathrm{H} 2$, a minimum $\mathrm{N} 2$ purge rate of $3 \mathrm{scfm}$ would dilute the $\mathrm{H} 2$ to approximately $0.13 \%$.

\section{N20 Generation in the PPT}

The recently proposed mechanism for nitrite radiolysis in precipitate slurry predicts $\mathrm{N} 20$ formation. N20 has been detected in the vapor space over irradiated simulant slurries. The question was raised whether the N20 produced might be enough to affect the MOC for benzene in air. A bounding estimate can be made as follows [9]:

Bases: One mole $\mathrm{N} 20$ forms from two moles nitrite Nitrite radiolysis is 0.013 gmols/liter-month

$6500 \mathrm{gal} \times \frac{0.013 \text { gmols nitrite }}{\text { liter slurry-month }} \times \frac{1 \mathrm{~mol} \mathrm{~N} 20}{2 \text { mols nitrite }} \times \frac{3.7851}{\text { gal }}$ $\times \frac{1 \text { month }}{730 \text { hrs }} \times \frac{1 \text { lbmol }}{453.6 \text { gmol }} \times \frac{359 \text { scf }}{1 \text { bmol }}=0.173 \mathrm{scfh} \mathrm{N} 20$

At typical purge flows of $20 \mathrm{scfm}$ or greater, the N20 concentration would be less than $0.015 \%$. If a minimum purge flow of 3 scfm is provided, the $\mathrm{N} 20$ concentration would be $<0.1 \%$. At this concentration the $\mathrm{N} 20$ would have essentially no effect on the MOC for benzene and air.

\section{Thermal Decomposition of Tetraphenylborate (TPB) slurries}

Thermal stability studies of potassium tetraphenylborate slurries have been conducted. $[10,11,12]$ At $90^{\circ} \mathrm{C}$, the decomposition of KTPB produces approximately $450 \mu \mathrm{gms}$ benzene/day-g KTPB. [10] Assuming $10 \%$ KTPB with $\mathrm{S}_{g}=1.03$, 


$$
\begin{gathered}
\frac{0.1 \text { lbs KTPB }}{\text { Ib slurry }} \times 1.03 \times \frac{8.33 \text { lbs slurry }}{\text { gal slurry }} \times \frac{453.6 \mathrm{gms}}{1 \mathrm{~b}} \\
=389 \frac{\mathrm{gms} \mathrm{KTPB}}{\mathrm{gal} \mathrm{slurry}} \\
\text { therefore, } \frac{\mathrm{d}[\mathrm{benz}]}{\mathrm{dt}}=\frac{450 \mu \mathrm{gms} \text { benz }}{\mathrm{day}-\mathrm{g} \mathrm{KTPB}} \times \frac{1 \mathrm{gm}}{10^{6} \mu \mathrm{gm}} \times \frac{389 \mathrm{gms} \mathrm{KTPB}}{\mathrm{gal} \mathrm{slurry}} \\
\times \frac{1 \mathrm{day}}{24 \mathrm{hrs}}=\frac{0.0073 \mathrm{gm} \mathrm{benz}}{\mathrm{hr} \text {-gal }}
\end{gathered}
$$

By comparison, the production of benzene by radiolys is has been measured to be $0.0015 \mathrm{gm}$ benz/hr-gal. [13] The estimated benzene production rate by thermal decomposition at $90^{\circ} \mathrm{C}$ is about five times greater than by radiolysis. The total benzene production rate by thermal decomposition at $90^{\circ} \mathrm{C}$ plus radiolysis would be

$$
6500 \mathrm{gal} \times\left(\frac{0.0073 \mathrm{gm}}{\mathrm{hr}-\mathrm{gal}}+\frac{0.0015 \mathrm{gm}}{\mathrm{hr}-\mathrm{gal}}\right) \times \frac{1 \mathrm{lb}}{453.6 \mathrm{gm}}=0.13 \mathrm{lbs} / \mathrm{hr} \text {. }
$$

To put this number in perspective, the design benzene rate for the pump pit PVVS is $25 \mathrm{lbs} / \mathrm{hr}$.

\section{Precipitate Temperature Iimit in an Air Purged Tank}

In reference 13, calculations were presented showing how benzene can be purged from precipitate slurries over time. These calculations included benzene generation by radiolys is but assumed normal operating temperatures; that is, no allowance was made for benzene generation by thermal decomposition. (At expected temperatures, thermal decomposition is negligible.) DWPF has a contingency plan which involves steam jet transfer of the precipitate slurry to the Recycle Pump Tank (RPT) in the event the PPT transfer pump is not operable. Since the RPT is not $\mathrm{N} 2$ purged, the plan first involves stirring and purging the benzene from the precipitate in the PPT prior to transfer. The calculations indicated the precipitate can then be safely transferred to the RPT as long as it is stirred occasionally to prevent benzene buildup. DWPE is aware of the necessity to monitor precipitate temperature under these conditions.

\section{Ounlity Assurance}

All the above discussion is based on a thorough analysis of published, reliable scientific data. The discussion is intended to provide ready reference and sample calculations for the team preparing the DWPF Pump Pit Process Requirements. The calculations in this document were checked by L. F. Landon. 


\section{References:}

1. N. E. Bibler, RADIOLYTIC H2 PRODUCTION FROM DWPF SLUDGE FEED SOLUTION, DPST-83-373, March 17, 1983.

2. Nuclear Regulatory Commission Guide 1.7, Revision 2, November 1978.

3. J. R. FOWler, DWPF ISOTOPIC DATA, DPST-84-971, February 21, 1985 .

4. DWPF BASIC DATA REPORT, Rev. 91, DPSP-80-1033.

5. D. D. Walker, RADIOLYSIS OF TETRAPHENYLBORATE: UNIVERSITY OF FLORIDA TRIP REPORT, DPST-84-827, October 18, 1984.

6. National Fire Codes, NFPA 69, EXPLOSION PREVENTION SYSTEMS, 1986.

7. R. A. Jacobs, FLAMMABILITY OF VAPOR MIXTURES FROM IN-TANK PRECIPITATION, DPST-88-573, October $28,1988$.

8. National Fire Codes, NFPA 325M, FIRE HAZARD PROPERTIES OF FLAMMABLE LIQUIDS, GASES, AND VOLATILE SOLIDS, 1984.

9. Personal communication with D. D. Walker, February, 1992.

10. Electronic mail message from D. D. Walker, February 6, 1992, copy attached.

11. Analytical Report, D. J. Coffin and S. R. Laas, Polymer Products Dept., Experimental Station, E. I. Dupont de Nemours \& Co., to W. V. Wright, Savannah River Laboratory, "QUANTITATION OE VOLATILES IN HEADSPACE OVER SIMULATED WASTE SLURRIES, Job \#820-1316, PRAL NOS. 82-7120-7122," April 20, 1983.

12. Analytical Report, D. J. Coffin, Polymer Products Dept., Experimental Station, E. I. Dupont de Nemours \& Co., to D. D. Walker, Savannah River Laboratory, "QUANTITATION OF BENZENE IN HEADSPACE OVER SIMULATED WASTE SLURRIES, JOb \#331-585, PRAL Nos. 83-4045-4047," September 27, 1983.

13. R. A. Jacobs and D. D. Walker, BENZENE EVOLUTION FROM PRECIPITATE SLURRY PUMP PIT TANKS, WSRC-TR-91-0478, August 15,1991 . 

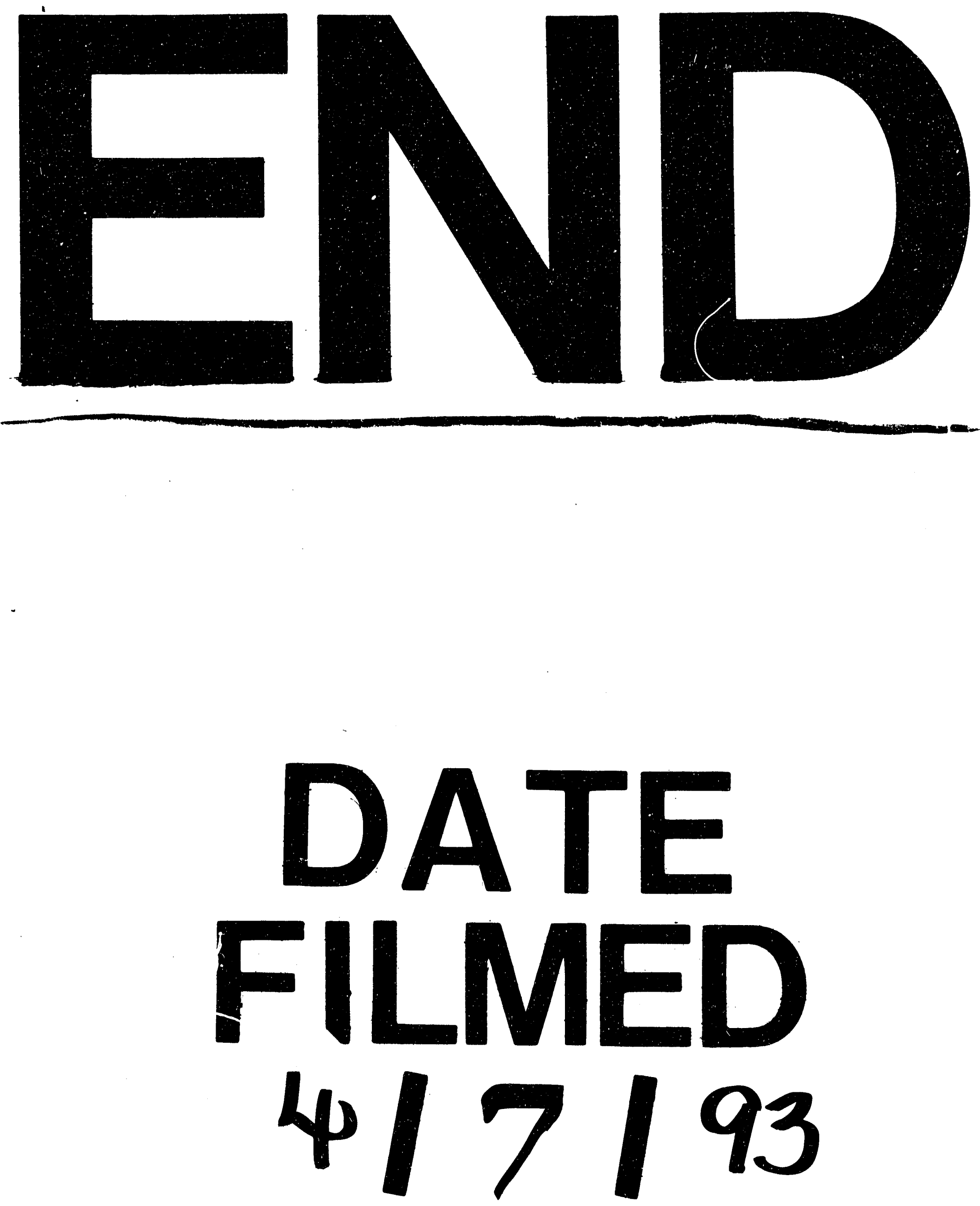
$\cdot$ 